\title{
THE DELIBERATIVE CITY
}

\section{Hoi Kong*}

In this paper, I will argue that general administrative law concerns about the legitimacy and effectiveness of rule-making have special force in the municipal zoning by-law context. In particular, I will argue that a particular, civic republican conception of legitimate state action offers the best justification for municipal regulation and provides the best normative foundation for developments in municipal consultation processes. In Part II, I will argue that the consultative processes in Quebec's zoning laws reflect a commitment to civic republican ideals, but that because of specific features of municipal regulation, these ideals are incompletely realized. In Part III, I will argue that a particular municipal institution - the ward council - enables the zoning process to better approximate civic republican ideals. I conclude this paper by arguing that ward councils not only strengthen the normative justifications for municipal regulation, they contribute to its effectiveness.

Dans cet article, je vais soutenir que les préoccupations du droit administratif général au sujet de la légitimité et l'efficacité de l'élaboration de règles ont une importance particulière dans le contexte de la réglementation municipale sur le zonage. En particulier, je vais soutenir qu'une certaine conception civique républicaine de l'action légitime de l'état offre la meilleure justification de la réglementation municipale et le meilleur fondement normatif pour les développements des processus de consultation municipaux. Dans la partie II, je vais soutenir que les processus de consultation des lois sur le zonage du Québec reflètent un engagement envers les idéaux civiques républicains mais qu'à cause de certains aspects précis de la réglementation municipale, ces idéaux ne sont pas complètement atteints. Dans la partie III, je vais soutenir qu'une institution municipale particulière - le conseil de quartier - fait que le processus de zonage se rapproche mieux des idéaux civiques républicains. Je termine l'article en soutenant que les conseils de quartier non seulement renforcent les justifications normatives de la réglementation municipale, ils contribuent à son efficacité.

\section{INTRODUCTION}

As others in this special issue have noted, scholars and practitioners of administrative law have long been concerned with how to design effective consultative rule-making

\footnotetext{
Assistant Professor of Law, McGill University. I thank participants in faculty workshops at the Faculties of Law at the University of Alberta, McGill University and Queen's University for incisive comments. I am also particularly grateful to participants in the Sixth Administrative Law Discussion Forum, Québec City, May 25-26, 2010, for their probing questions. For conversations that greatly assisted in developing this paper, I thank Richard Briffault, Robert Ferguson, Rod Macdonald, Chuck Sabel, and Bill Simon. For excellent research assistance, provided at various stages of the project, I thank Adela Maciejewski Scheer, Tim Petrou, Owen Ripley, and Lisa Smith. I acknowledge the support of the Borden Ladner Gervais Fellowship program for funds that were instrumental in bringing this paper to conclusion.
} 
processes. In his contribution, Professor Peter Strauss argues that advances in technology have the potential to make administrative rule-making consultations in the United States more accessible and transparent. ${ }^{1}$ In a similar vein, Professor France Houle examines how Canadian civil servants have responded to the recent Cabinet Directive on Streamlining Regulation, ${ }^{2}$ which makes stakeholder consultations a mandatory part of the Federal Government's regulation-making process. ${ }^{3}$ Two general concerns motivate the scholarly focus on the design of consultative processes in the rulemaking context. First, as Strauss notes, this focus reflects a general concern about the democratic legitimacy of rule-making by the executive branch. ${ }^{4}$ Second, as Houle argues, governments face increasingly complex governance challenges and as a consequence, have turned to collaborating with stakeholders in order to ensure that their governance initiatives are effective. Administrative law scholars are elaborating normative theories and developing analytical tools to assess these emerging forms of collaboration. $^{5}$

In this paper, I will argue that the concerns about the legitimacy and effectiveness of rule-making have special force in the municipal zoning by-law context. ${ }^{6}$ In particular, I will argue that a particular, civic republican conception of legitimate state action offers the best justification for municipal regulation and provides the best normative foundation for developments in municipal consultation processes. Before I turn, in the main body of this paper, to the detailed substantive and institutional arguments, I will very briefly introduce this paper's theoretical position and I begin with the normative theory that is the counterpoint to my position.

Pluralist theories of democracy have exerted considerable influence on the theoretical writing on municipal law. These theories place a premium on government's capacity to respond to citizen preferences and they understand citizen autonomy to be defined primarily in terms of the pursuit of private preferences.

1 Peter Strauss, "Implications of the Internet for Quasi-Legislative Instruments of Regulation" (2010) 28:2 Windsor YB Access Just.

2 Treasury Board of Canada Secretariat, Cabinet Directive on Streamlining Regulation, Section 2.0, online: TBS < http://www.tbs-sct.gc.ca/riqr/directive/directive01-eng.asp>.

3 France Houle, "Consultation During Rule-Making: A Case Study Of The Immigration And Refugee Protection Regulation” (2010) 28:2 Windsor YB Access Just.

4 He writes: "The legitimacy of permitting unelected officials to create binding legal texts is an enduring problem for any democracy." Supra note 1

5 Professor Houle cites Lester Salamon's New Governance Approach as a particularly influential account of these developments. Supra Note 3. In his presentation at the conference, Professor Denis Lemieux applied the New Governance Approach to environmental regulation. See Dennis Lemieux, "Economic Instruments and Environmental Regulation" (Paper Delivered At the Sixth Administrative Law Discussion Forum, Québec City, 25 May 2010), [Unpublished].

6 Some authors classify Canadian municipalities as administrative bodies, albeit with political functions. See e.g. René Dussault \& Louis Borgeat, Administrative Law: A Treatise, vol. 1 (Toronto: Carswell, 1985) at 188-89 and Pierre Issalys \& Denis Lemieux, L'Action gouvernementale: précis de droit des institutions administrative, 3rd ed (Cowansville: Yvon Blais, 2009) \5.5.

7 The literature on such theories is voluminous. For the contrast drawn in the main text, see Frank Michelman, "Political Markets and Community Self-Determination: Competing Judicial Models of Local Government Legitimacy" (1977-78) 53 Ind LJ 145 at 148. For prominent contemporary articulations of the pluralist position, see William A. Fischel, "Public Goods and Property Rights: Of Coase, Tiebout and Just Compensation” (August 7, 2000), online: Dartmouth College <http://www.dartmouth.edu/ wfischel/Papers/00-19.pdf >. See also William A. Fischel, The Homevoter Hypothesis (Cambridge: Harvard University Press, 2001) [Fischel, Homevoter]; Edward 
Perhaps the most prominent exponent of this theory, Professor William Fischel, argues that American homeowners are passionately engaged in local government because they seek through zoning regulations "insurance" for their homes. According to Fischel, home values are dependent on their surroundings, and it is difficult, if not impossible to purchase private insurance to protect against neighborhood change. As a consequence, he claims, local government becomes the vehicle through which homeowners control their surroundings to protect home value. For Fischel, local government is where homeowner's private preferences are cashed out. ${ }^{8}$

In this paper, I will offer a contrasting, civic republican theory of municipal institutions, which rests on a different conception of the relationship between the state and citizens, of citizen autonomy and of policy making. Rather than primarily consisting of freedom to pursue preferences, autonomy in this view is conceived of as freedom from domination. In civic republican theory, it is unjustifiable for the state merely to give effect to the private preferences of citizens. To be justified, state action must rest on publicly defensible reasons, reasons, that is, which appeal to some understanding of the public good. ' To permit otherwise would allow the state to affect some citizens' choices in ways that are not defensible to them. Such an outcome would subject citizens to state action that is merely an expression of will, not a manifestation of public reasons, and domination is the fact of being vulnerable to this kind of state action. ${ }^{10}$ Although authors have drawn a distinction between pluralism and civic republicanism in the local government context, ${ }^{11}$ none has worked out a civic republican approach to local government law with the degree of detail and attention to the Canadian, and in particular, the Quebec context that I attempt in this paper.

In Part II, I will argue that the consultative processes in Quebec's zoning laws reflect a commitment to civic republican ideals, but that because of specific features of municipal regulation, these ideals are incompletely realized. In Part III, I will argue

Zelinsky, "Metropolitanism, Progressivism and Race" (1998) 98 Colum L Rev 665. For a particularly influential development of the initial Tiebout insight, see Vincent Ostrom et al., "The Organization of Government in Metropolitan Regions: A Theoretical Inquiry” (1961) 55 American Political Science Review 416. For a critical survey of writing on the model, see Wallace E. Oates, "The Many Faces of the Tiebout Model" in William A. Fischel, ed, The Tiebout Model at Fifty (Cambridge, Mass.: Lincoln Institute of Land Policy, 2006) 21. For Canadian contributions to the literature, see Andrew Sancton, Merger Mania: The Assault on Local Government (Kingston: McGill-Queen's University Press, 2000) at 74-75, 91-92, 167; Robert L. Bish, "Local Government Amalgamations: Discredited Nineteenth-Century Ideals Alive in the Twenty-First" (March 2001) C.D. Howe Institute Commentary 150, online: C.D. Howe Institute < http://www.cdhowe.org/pdf/bish.pdf>.

8 Fischel, Homevoter, ibid.

9 For an articulation of this requirement of reasoning in terms of the public good, see T.R.S. Allan, Constitutional Justice: A Liberal Theory of the Rule of Law (Oxford: Oxford University Press, 2001) at 287: "No one should be criticized for confronting his fellow citizens with arguments that he thinks pertinent to any moral or political issue, however difficult or divisive, provided only that he claims no special knowledge or authority that precludes rational inspection and challenge." For a general defense of civic republican legal theory, see Samantha Besson \& José Luis Martí, "Law and Republicanism: Mapping the Issues" in Samantha Besson \& José Luis Martí, eds, Legal Republicanism: National and International Perspectives (Oxford: Oxford University Press, 2009) 3.

10 On this conception of autonomy, see Philip Pettit, Republicanism: A Theory of Freedom and Government (Oxford: Oxford University Press, 1997) c. 1.

11 See the overview of the literature in Robert C. Ellickson \& Vicki Been, Land Use Controls: Cases and Materials (New York: Aspen Publishers, 2005) at 47-50. 
that a particular municipal institution - the ward council - enables the zoning process to better approximate civic republican ideals. I conclude this paper by arguing that ward councils not only strengthen the normative justifications for municipal regulation, they contribute to its effectiveness. I begin by working out in more detail the civic republican position that I advance and by considering the deliberationenhancing features of the law of zoning in Quebec.

\section{CIVIC REPUBLICANISM AND THE DELIBERATIVE FAILURES OF MUNICIPAL LAW}

Quebec zoning laws' consultative processes facilitate public deliberation. By affording citizens the opportunity to shape the norms that govern them, these processes aim to place municipal officials in a position to consider the interests of those affected by the regulation. By so limiting the likelihood that the state will act in ways that are not justifiable to those subject to regulation and by providing opportunities to contest proposed state action, these processes serve civic republican ends. They prevent non-domination (and not mere non-interference), because they provide opportunities for the state to justify its actions (or non-actions) to citizens and they enable citizens to engage actively in self-rule. ${ }^{12}$ Civic republican theorists have disagreed about the capacity of deliberative processes such as these to yield civic republican ends and before I turn to consider the details of Quebec's zoning regime, I will briefly engage this debate.

\section{A. Civic Republicanism and Deliberative Democratic Institutions}

Professor Richard Bellamy has argued that pervasive and persistent disagreement about the substance of political, moral and legal decisions is an inescapable feature of political life, ${ }^{13}$ and that the civic republican injunction against domination requires an institutional response to this state of affairs that extends to citizens "equal concern and respect as autonomous reasonors." ${ }^{14}$ Bellamy argues that democracies with thriving political party systems provide just such institutions. It is in these systems, Bellamy argues, that citizens can participate on equal political terms with one another. He writes:

So long as a system of equal votes, majority rule and party competition - however interpreted - offers a plausible system for giving citizens an equal say in the ways collective arrangements are organized - including those of the democratic process - then a

12 Bellamy argues that it is this focus on self-rule that distinguishes civic republicanism from liberal theories which are concerned primarily with limits on the power of government. Richard Bellamy, Political Constitutionalism: A Republican Defense of the Constitutionality of Democracy (Cambridge, U.K.: Cambridge University Press, 2007) at 156: "Seeing freedom as liberty from mastery rather than freedom from interference brings out this common rationale (that relating to individuals as autonomous agents who should be allowed to choose and think for themselves, even when that involves making mistakes), while revealing why we should see limited government in terms of popular controls rather than a priori restrictions on certain kinds of governmental intervention".

13 For this point, he draws on Professor Jeremy Waldron's work. See e.g. Jeremy Waldron, “The Core of the Case Against Judicial Review" (2006) 115 Yale LJ 1346.

14 Bellamy, supra note 12 at 191. 
self-constituting democratic constitution that avoids dominating through arbitrary rule will have been secured.

Modern political parties have particular significance for Bellamy because, he argues, they track broad ideological differences that cut across a whole range of issues in society. ${ }^{16}$ According to him, political parties offer citizens bundles of policy proposals that reflect the policy compromises and inputs of interest group coalitions that operate within a broadly shared ideological framework. Political parties, Bellamy argues, enable citizens to engage in public reasoning by voting on these policy bundles.

Moreover, Bellamy identifies seven features of public reasoning which, taken together, exemplify the civic republican virtue of non-domination. They are: 1) a commitment to openness and transparency; 2) an ethos of public-spiritedness, which guides political proceedings; 3 ) the presence of publically available rules, reasons and conventions; 4) a focus on the public good rather than private interests; 5) the use of reasons that are accessible to all members of the public; 6) the fact that reasoning is undertaken by the public; 7) the production of decisions that will be found acceptable by all members of the public. ${ }^{17}$ Bellamy argues that political parties, of the kind for which he advocates, facilitate political discourse which evidences all these features of public reasoning. ${ }^{18}$

Although Bellamy's main theoretical opponents are "legal constitutionalists" who advocate for constitutionally entrenched rights, the substantive content of which is determined by the judiciary, he also directs criticisms towards deliberative democrats who advocate for deliberative institutions, such as citizens' juries, which are designed to minimize the likelihood participants will appeal to "prejudiced, uniformed or unreasoned arguments." ${ }^{\prime \prime}$ Bellamy notes that experts typically constitute such bodies and their agendas, and that because there are no guarantees that these constituting acts track the interests of the citizens rather than the paternalistic views of experts, these institutions create a risk that experts will dominate citizens. Bellamy further argues that proponents of deliberative democracy assume that the outcome of a properly structured deliberation will be a principled consensus, which yields a right answer to contentious public disagreements. ${ }^{20}$ But, according to Bellamy, this focus on substantive outcomes is misguided, given the fact of pervasive and persistent political disagreement. Under these conditions, he argues, right answers are unattainable ${ }^{21}$ and the appropriate focus of civic republican analytical attention should instead be on deliberative procedures and institutions that evince the seven features of public reasoning identified above. Such procedures and institutions, he argues,

5 Ibid at 220-21.

16 Bellamy identifies two broad sets of such cleavages - the centre-periphery and the right-left. Ibid at 233-39.

17 Ibid at 179 .

$18 \quad$ Ibid at 221-39.

19 Ibid at 190.

20 Ibid at 188. Bellamy argues further that the deliberative democratic institutions can sometimes exacerbate domination. Ibid at 189. I address that critique in my discussion of the institutional design features of ward councils. See below.

21 See Waldron, supra note 13. 
provide effective safeguards against domination, in particular, because they increase the likelihood that political activity will yield mutually acceptable compromises. According to Bellamy, compromises of this sort evidence a due regard for citizens' substantive views of policy. ${ }^{22}$

Bellamy's argument is primarily concerned with debates about the role and appropriateness of judicial review, in the context of constitutional rights. Whatever the merits of the argument in that context, they do not apply in the rule-making context and, what is of particular relevance to this paper, his arguments against deliberative democracy do not apply in the context of the creation of zoning by-laws. Let us begin by taking off the table Bellamy's claim that deliberative democrats are committed to right answers to policy disagreements. A commitment to deliberative democracy does not necessarily entail a commitment to right answers. One might argue instead that the value of deliberative democratic procedures lies in the fact that they provide citizens with opportunities to participate directly in the state's decisionmaking. As we shall see below, if designed appropriately, these procedures provide occasions for officials to engage in public reason-giving and for citizens to engage in self-rule. ${ }^{23}$ These features of appropriately designed deliberative procedures provide civic republican safeguards against domination by the state and a civic republican can advocate for these procedural safeguards without reference to arguments about the correctness or even the wisdom of the substantive outcomes that result from these procedures.

Now that we have considered and rejected Bellamy's arguments linking theories of deliberative democracy to claims about right answers to political disputes, we can turn to address his claim that because experts control the agendas of deliberative democratic institutions such as citizen's juries, and there are no guarantees that these experts, when deciding upon the content of these agendas, are responsive to the interests of citizens. This concern about expertise is reflected in Bellamy's general argument about the role of expertise in political decision-making. He writes:

It might be argued that some political decisions are purely technical, regarding the choice of the most appropriate means to agreed ends. However, putting to one side the fact that experts frequently disagree even in quite technical areas, such as nuclear power, most policy assessments tend to involve politically contentious moral and ideological judgments at some level or another. $^{24}$

22 Bellamy defends the value of such compromises when he writes: "compromise often goes deeper than ... attempts to 'split the difference'. Instead, there is a genuine effort to integrate the different concerns and the various weightings they have for those involved. ... For a genuine process of 'hearing the other side' produces compromises that are not only strategic alternations of the means to better pursue self-interested ends but also promote changes to these ends. In this way, the various sides are shown not only a formal respect as rights-bearers but also equal concern with regard to their substantive views of what their rights are and the ways they wish to exercise them." Bellamy, supra note 12 at 193-94.

23 See below, Part III. 
There are two related arguments here: the first targets the specific role of experts in creating deliberative democratic institutions and the second addresses the general role of expertise in political decisions. The first argument about the role of experts can be answered by noting that some deliberative democratic institutions are constituted by actors with democratic pedigree, and not by experts. A number of such institutions, including the ward councils, are created at the initiative of ordinary citizens and under the authority of legislation. ${ }^{25}$ Moreover, as we shall see, ward council members are democratically elected and their agendas are set by elected officials. ${ }^{26}$ The composition and agendas of these institutions are established through democratic means, not by experts and as a result, Bellamy's first argument against deliberative democratic institutions simply does not apply to a significant set of these institutions.

Bellamy's second, more general argument about the role of expertise in political decision-making leads him to the conclusion that "the only peers entitled to choose between alternative collective moral and political choices are not the community of experts in these (specialized regulatory) fields but the community of all moral and political reasonors." ${ }^{27}$ This argument specifically targets the claim that judges are worthy of deference on constitutional matters because they possess relevant expertise. One may accept Bellamy's claim in the context of judicial review, yet argue that the claim requires more nuance in the context of the administrative state. One of the central rationales for administrative agencies is that they have specialized expertise that legislatures do $\operatorname{not}^{28}$ and one of the key reasons for regulations is that legislatures lack the expert knowledge and time necessary to generate legislation that tracks the on-the-ground developments in specific regulatory domains. ${ }^{29}$ In the context of the administrative state, it may be true that "the community of all moral and political reasonors" indirectly creates, through legislation, the framework within which administrative agencies work, but legislation also delegates to the administrative agencies the authority to make specific regulatory choices that have "collective moral and political" dimensions.

25 See below. For a description of deliberative institutions that are not constituted by experts, see Gessica Gropp et al "La Participation citoyenne et le développement des communautés: fiches descriptive de 10 expériences de participation citoyenne", Doc. 2, online: Institut national de santé publique < http://www.i-n-s-p-q.qc.ca/Developpement- Social/docs/participation_citoyenne_10_ experiences.pdf $>$.

26 See below, Part II.

27 Bellamy, supra note 12 at 169

28 John Willis, "Canadian Administrative Law in Retrospect" (1974) 24 UTLJ 225 and John Willis, "Lawyers' Values and Civil Servants' Values" (1968) 18 UTLJ 351. For the rise of expertise in municipal governance during the New Deal era, see C. Richard Tindal \& Susan Nobes Tindal, Local Government in Canada (Toronto: Nelson Education, 2004) c. 2. For an examination of how the idea of planning as a science emerged in this era, see Robert H. Nelson, "Zoning Myth and Practice: From Euclid Into the Future" in Charles M. Haar \& Jerold S. Kayden, eds, Zoning and the American Dream: Promises Still to Keep (Chicago: Planners Press, 1989). For an examination of this movement, stressing its anti-corruption motivations, see Gerald Frug, City Making: Building Communities Without Building Walls (Princeton: Princeton University Press, 1999) at 51-52. In the American administrative law context, see Richard Stewart, "The Reformation of American Administrative Law" (1974-1975) 88 Harv L Rev 1667 at 1678 and Martin Shapiro, Who Guards the Guardians? Judicial Control of Administration (Athens, Georgia: University of Georgia Press, 1988) at 36-38 and Cass R. Sunstein, After the Rights Revolution (Cambridge, Mass.: Harvard University Press, 1990) c. 1.

29 See generally Harry Arthurs, "Regulation-Making: The Creative Opportunities of the Inevitable" (1970) 8 Alta L Rev 315. 
Of course there is much debate about how and whether these choices and delegations are subject to democratic controls. ${ }^{30}$ Nonetheless, the very fact of this delegated authority suggests that the binary choice offered by Bellamy - the community of experts or the community of all moral and political reasonors - is, in the context of the administrative state, not clear-cut. ${ }^{31}$ In addition, this binary opposition misses the complex interplay between expert and citizen opinion in the administrative state. There may be some circumstances in which experts provide necessary guidance to ordinary citizens and enable the latter to make informed judgments about public policy issues. ${ }^{32}$ For instance, ombudsman offices, through their investigative and reporting functions assist citizens in monitoring government action; $^{33}$ human rights commissions often have similar educational roles, ${ }^{34}$ as do entities charged with managing and overseeing victims of crime compensation funds. ${ }^{35}$ In addition, there may be conditions under which it is only with the input of those affected by regulation that policy makers, including experts, can create effective regulation. ${ }^{36}$ This is particularly the case where private commercial actors ${ }^{37}$ or

30 For an overview of this debate in the American context, see Steven P. Croley, "Theories of Regulation: Incorporating the Administrative Process" (1998) 98 Colum L Rev 1 and in the Canadian context, see Genevieve Cartier, "Procedural Fairness in Legislative Functions: The End of Judicial Abstinence?" (2003) 53 UTLJ 217 at 218. For a civic republican defense of the administrative state, which argues that administrative agencies, because of their expertise and delegated authority, are better positioned to engage in public reasoning than legislatures or courts, see Mark Seidenfeld, "A Civic Republican Justification for the Bureaucratic State” (1991-1992) 105 Harv L Rev 1515 at 1542. He writes: "Administrative agencies, however, fall between the extremes of the politically overresponsive Congress and the over-insulated courts. Agencies are therefore prime candidates to institute a civic republican model of policymaking."

31 For a detailed civic republican analysis of the administrative state, which acknowledges the complex interplay between legislatures and administrative agencies to whom legislatures delegate authority to agencies precisely because these agencies are better positioned than the electorate at large or its elected representatives to engage in detailed policy-making, see Henry S. Richardson, Democratic Autonomy: Public Reasoning about the Ends of Public Policy (Oxford: Oxford University Press, 2002) at 224. He writes: "there are good reasons for us to hope that agencies develop substantive expertise in the course of pursuing projects that we, through our legislature, have decided that they ought to pursue." On the capacity of regulation to perform this function, generally, see Cass R. Sunstein, "Interest Groups in American Public Law" (1985-86) 38 Stan L Rev 29; see also Glen Staszewski, "Reasongiving and Accountability" (2009) 93 Minn L Rev 1253.

33 See e.g. the reporting functions set out in the Public Protector Act, R.S.Q. c. P-32, s. 27.

34 See e.g. the discussion of the educational mandate of the Ontario Human Rights Commission in Mary Cornish et al, Enforcing Human Rights in Ontario (Aurora, Ont.: Canadian Law Book, 2009) at 7082.

35 For an overview of services provided by Victims' Services in Saskatchewan, see Victims Services Branch, online: Government of Saskatchewan <http://www.justice.gov.sk.ca/victimsservices>.

36 See Jason Corburn, "Bringing Local Knowledge into Environmental Decision Making” (2003) 22 Journal of Planning Education and Research 420.

37 This is one of the standard arguments for recourse to government by contract, and in particular, by public-private partnerships. For an historical overview of these debates, see William J. Novak, "Public-Private Governance: A Historical Introduction" in Jody Freeman and Martha Minow, eds, Government By Contract (Cambridge, Mass.: Harvard University Press, 2009) 23. For the specific advantages of public-private partnerships, see E.S. Savas, Privatization and Public-Private Partnerships (New York: Seven Bridges Press, 2000) at 238-41. For an overview of the uses of these partnerships in Canada, see Conference Board of Canada, Steering A Tricky Course: Effective Public-Private Partnerships for the Provision of Transportation Infrastructure and Services, online: Conference Board of Canada $<$ http://www.conferenceboard.ca/documents.aspx?did=2751>. For a general assessment of private- 
citizens, ${ }^{38}$ and not officials, have the requisite level of on-the-ground knowledge for regulation to be effective. In this paper, we shall see that municipal processes incorporate both kinds of expert-citizen interplay.

In this section, I have staked out specific theoretical ground in contemporary civic republican debates. In particular, I have argued that, contra Bellamy, deliberative democratic institutions are not ruled out by civic republican theory and in particular, by civic republican accounts of the administrative state. With the theoretical space thus narrowed, I turn now to consider some of the consultative processes of Quebec municipal law and to examine how they manifest a commitment to civic republicanism.

\section{B. Consultation Requirements}

Municipal law statutes in Canada and Quebec impose notice, publicity and consultation requirements on municipal councils when they pass zoning by-laws. ${ }^{39}$ In Quebec, after a municipal council has adopted a draft by-law, the clerk or secretary treasurer of the municipality must submit a certified copy to the relevant regional authority. ${ }^{40}$ He or she must post in the office of the municipality notice of a public meeting to discuss the proposed by-law and must publish the notice in a newspaper." In addition, legislation prescribes that the municipality shall hold a public hearing on a draft by-law, at a date, time, and place of the council's choosing. ${ }^{42}$ At that meeting the mayor or the mayor's designate presides, and according to the legislation, shall explain the draft by-law and hear anyone who wants to express an opinion about the draft. $^{43}$ Some jurisdictions require additional consultations at the sub-municipal (borough or ward) level ${ }^{44}$ and some consultations are conducted by a specialized office of a municipality, either at the request of the municipal council, or pursuant to applicable legislation. ${ }^{45}$ If the by-law does not contain provisions that are potentially subject to referendum, the draft by-law is adopted after the public meeting, with or without changes. ${ }^{46}$

public partnerships, including their democratic and efficiency dimensions, see Pauline Vaillancourt Rosenau, "The Strengths and Weaknesses of Public-Private Policy Partnerships" in Pauline

Vaillancourt Rosenau, ed, Public-Private Policy Partnerships (Cambridge, Mass.: MIT Press, 2000) 217.

38 See e.g. the initiatives described in Archon Fung, "Deliberative Democracy, Chicago-Style: Grassroots Governance in Policing and Public Education" in Archon Fung \& Erik Olin Wright, eds, Deepening Demcoracy: Institutional Innovations in Empowered Participatory Governance (New York: Verso, 2003) 111.

39 These requirements are subject to judicial oversight. See Wiswell v. Metropolitan Corporation of Greater Winnipeg, [1965] S.C.R. 512 and Marc-André LeChasseur, Zonage et urbanisme en droit municipal québécois (Montreal: Wilson \& LaFleur, 2009) at 70.

40 An Act Respecting Land Use Planning and Development, R.S.Q. c. A-19.1, s. 124 [L.A.U.].

41 Ibid. at s.126. Failure to provide notice in the manner prescribed may result in the by-law's being quashed. See William Buholzer, Halsbury's Laws of Canada-Planning and Zoning (Markham, Ont.: LexisNexis, 2008) at 386.

42 L.A.U., supra note 40 at s. 125.

43 Ibid. at s. 127

44 See Charter of ville de Lévis, R.S.Q. c. C-11.2, s. 86(1); Charter of ville de Québec, R.S.Q. c. C-11.5, s. 74.1.

45 See Charter of the ville de Montréal, R.S.Q. c. C-11.4, s. 83.

46 L.A.U., supra note 40 at s. 134. Buholzer notes that unlike other provincial legislation, Quebec law does not require an additional public hearing if council alters a draft by-law after the public hearing. Buholzer, supra note 41 at 395. 
For those provisions of draft zoning by-laws which are subject to referendum requirements, ${ }^{47}$ the degree of citizen scrutiny is even greater. If a draft zoning by-law contains a provision that is subject to a referendum, the person responsible for explaining the by-law in the public meeting must identify the provision and explain the right that certain persons have to make an application to submit the provision to approval to qualified voters for approval. ${ }^{48}$ After this meeting, the council must adopt a second draft by-law, and no provision in this second draft by-law can be included that does not relate to a matter included in the first draft by-law. ${ }^{49}$ A summary of this draft by-law may be produced by the municipality and may be made available free of charge to anyone who requests it. ${ }^{50}$ The legislation then sets out the conditions under which an application for a referendum concerning such a draft by-law may be made ${ }^{51}$ and requires that the municipal clerk or secretary treasurer issue a public notice of the second draft by-law that includes information about who may sign onto an application with respect to which provisions, as well as the requirements for a valid application. ${ }^{52}$ If no valid applications are made, council must adopt the draft by-law without change. ${ }^{53}$ If a valid application has been received, the by-law must be approved by qualified voters, in accordance with the relevant legislation. ${ }^{54}$ If a provision receives a majority of affirmative votes (or the amount specified in the provisions governing the referendum), the by-law is deemed to be approved by the qualified voters $^{55}$ and comes into force, subject to subsequent approval processes to ensure conformity with the objectives of the relevant land use planning and development plan. ${ }^{56}$

These process requirements impose on state officials a requirement to make public their decisions, to open them to direct citizen scrutiny and to justify them directly to citizens. They therefore appear to satisfy the civic republican criteria for non-domination that we considered above. Yet several well-established criticisms of municipal governments suggest that such processes fail to function effectively, in part because municipal governments themselves are imperfect forums of deliberation. I turn now to raise these criticisms, before introducing institutions that can answer them. We will see that in addition to providing a justificatory account of municipal law, civic republicanism can generate institutional design proposals.

\section{The Deliberative Failures of Municipal Councils}

Consider first a criticism of the representativeness of municipal institutions. Municipal governments are susceptible to being dominated by local majorities who are indifferent or hostile to minority interests, and therefore they can systematically

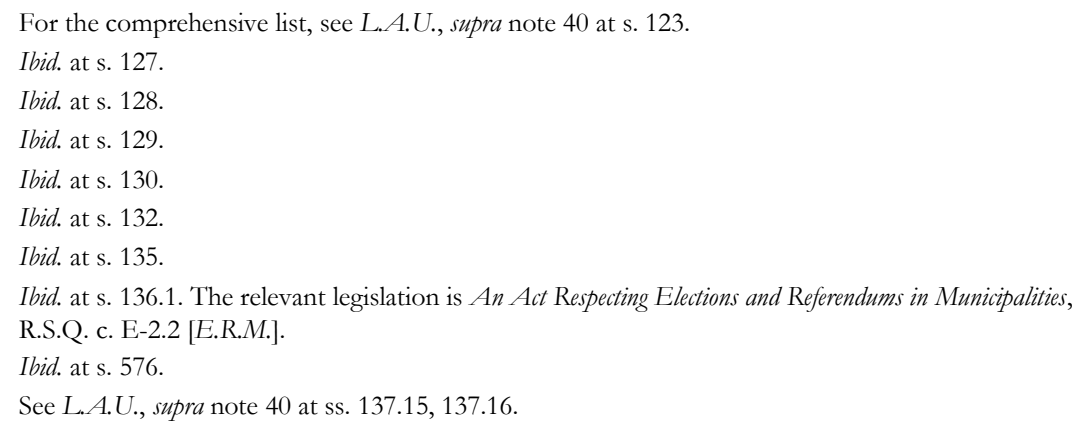


fail to represent those interests. An extensive literature suggests that standard public law problems of majoritarianism are intensified when political jurisdictions are small. ${ }^{57}$ In small jurisdictions there is a high risk of homogeneity and, as a consequence, of persistent majority control of political institutions. This theoretical insight has been borne out by experience. ${ }^{58}$ In its most intense form, this majority control can result in the physical exclusion of minorities from municipalities. Because municipalities have extensive control over land use regulations within their jurisdictions, majorities within already homogeneous municipalities can reinforce that homogeneity by enacting exclusionary measures. "Exclusionary zoning" occurs in wealthier municipalities, where residents seek to protect property values and limit demand and expenditure on social services by preventing lower-income residents from residing within their borders. A standard mechanism of exclusionary zoning is a by-law that limits residential housing to single-family units on large lots. Because only higher income households can afford this kind of housing, such by-laws exclude lower income households. ${ }^{50}$

In addition to this problem of majoritarian dominance, there is a second way in which municipal institutions can fail to represent significant democratic interests. Municipal governments are susceptible to being dominated by intensely motivated and well-resourced minorities, and therefore may act in ways that are contrary to the preferences of the majority. ${ }^{60}$ The general situation of small group dominance has been addressed extensively within public choice literature and in broad outlines, it is as follows. The individual preferences of members of a group which represents the majority of the population on a given issue can be of relatively low intensity. These individuals will not be sufficiently motivated to publicly influence government policy and thereby give effect to their preferences. Nonetheless, when aggregated, their preferences can outweigh those of any other group. By contrast, individuals in a second group may each have intense preferences with respect to an issue. This group may numerically constitute a minority within the jurisdiction and, when aggregated, the weight of their preferences may be lower than the aggregated preferences of the majority. Yet the individuals in this minority can be highly motivated to shape government policy, and when those who share such preferences are well-resourced, they can influence government to give effect to their preferences. ${ }^{61}$

This scenario describes land developers' influence within municipalities. Developers are well-resourced and highly motivated to influence municipal land use

57 See e.g. Carol M. Rose, "New Models for Local Land Use Decisions" (1984-85) 79 Nw UL Rev 1155 at 1159-60; Christopher Serkin, "Big Differences for Small Governments: Local Governments and the Takings Clause" (2006) 81 NYUL Rev 1624.

58 See e.g. Richard C. Schragger, “Consuming Government” (2003) 101 Mich L Rev 1824 at 1834, Sheryl D. Cashin, "Localism, Self-Interest and the Tyranny of the Favored Quarter: Addressing Barriers to the New Regionalism” (2000) 88 Geo LJ 1985 at 1991-2015, Richard Briffault, “Our Localism, Part II: Localism and Legal Theory" (1990) 90 Colum L Rev 346 at 393.

59 On exclusionary zoning and its effects generally, see Richard Briffault, "Localism and Regionalism" (2000) 48 Buff L Rev 1 at 25-26 and Myron Orfield, Metropolitics (Washington, D.C.: Brookings Institution, 1997) at 5-6.

60 Neil K. Komesar, Law's Limits: The Rule of Law and the Supply and Demand of Rights (Cambridge, U.K.: Cambridge University Press, 2001) c. 4.

61 On this point about the relative advantages of small and large groups, see Mancur Olson, The Logic of Collective Action: Public Goods and the Theory of Groups (Cambridge, Mass.: Harvard University Press, 1971) at 58-59. 
regulation. Residents who constitute the majority within a municipality may prefer land use regulations that are at odds with those sought by developers, but because each of these residents is significantly less motivated than developers to participate in planning processes, they will not participate or will not participate as intensely, and their preferences will go unsatisfied. ${ }^{62}$ In addition, participation in land use processes may represent a cost to residents that they cannot afford, either because they cannot afford to spend to participate (i.e., by paying for child-care or transportation costs) or because work obligations prevent them from participating. ${ }^{63}$ As a result, the minority preferences dominate over those of the majority and municipal institutions fail to represent a democratically significant set of interests.

Consider next a more direct criticism of participatory processes in municipalities. Citizen involvement in these processes is voluntary and the empirical literature strongly suggests that when participatory processes are of this nature, some groups are significantly over-represented. Those individuals who have significant time and intellectual and monetary resources tend to participate most effectively in voluntary processes. $^{64}$ By contrast-as we have just seen-individuals whose work or family circumstances make it burdensome to participate in voluntary institutions typically under-engage. Moreover, among those who do participate in voluntary participatory settings, there are individuals who are unable to express themselves in the vernacular of the educated professional classes. The empirical literature suggests that such individuals tend to defer to those more comfortable in that vernacular. ${ }^{65}$ At the municipal level of governance, this problem is compounded by the structure of meetings that are open to the public. In general, citizens have very limited time to speak and as a result, often do little more than air grievances that do not occasion reasoned engagement. ${ }^{6 \sigma}$

62 Komesar, supra note 60 . For an argument that site-specific land-use decisions are highly likely to evidence capture, precisely because there is insufficient legislative log-rolling and deliberation, see Rose, supra note 57 at $1159-60$.

63 Organizations that support deliberative processes sometimes attempt to overcome these limitations by covering transportation costs, providing child-care services or offering modest stipends. See e.g. Josh Lerner, "Participatory Budgeting in Canada" in Daniel Chavez \& Einar Braathen, eds, Progressive Cities (Oslo: Norwegian Institute for Urban and Regional Research, forthcoming), online: Transnational Institute <http://www.tni.org/archives/newpol-docs_pbcanada> and Daniel Schugurensky, "The Tango of Citizenship Learning and Participatory Democracy" in Karsten Mundel \& Daniel Schugurensky, eds, Lifelong Citizenship Learning, Participatory Democracy and Social Change (Toronto: Transformative Learning Centre, 2004) 607.

64 Elena Fagotto \& Archon Fung, "Empowered Participation in Urban Governance: The Minneapolis Neighborhood Revitalization Program" (2006) 30 Journal of Urban and Regional Research 638 at 643.

65 Lynn Sanders, “Against Deliberation” (1997) 25 Political Theory 347.

66 See e.g. Heather Campbell \& Robert Marshall, "Public Involvement and Planning: Looking Beyond the One to the Many" (2000) 5 International Planning Studies 321 at 331. In the Canadian context, see Mariana Valverde \& Ron Levi, "Freedom of the City: Canadian Cities and the Quest for Governmental Status" (2006) 44 Osgoode Hall LJ 409 at 441 for a description of such unreflective discourse.

provincial law requires cities contemplating zoning changes to hold public meetings and consultations in often complicated and expensive ways. This obligation gives a platform to those who oppose inclusionary measures; they are generally more educated and better equipped to participate in meetings, petitions and phone calls to councilors than those who are the potential beneficiaries of inclusionary zoning measures. In Toronto, predictably, most of the "untold number of community 
The literature suggests, then, that municipal governments are susceptible to a variety of conditions that lead to deliberative failures. Municipal councils can be dominated by majority or minority interests that are unresponsive to segments of the electorate, and municipal processes can be overly solicitous of certain privileged voices. The challenge for the remainder of this paper lies in considering one kind of institution, the ward council, which is capable of overcoming these conditions. I begin by setting out the structure of the ward councils before turning to argue that they respond to the deliberative failures of municipal governments.

\section{WARD COUNCILS AS DELIBERATIVE INSTITUTIONS}

\section{A. The Structure of Ward Councils}

The structure of ward councils is complex and I will begin my discussion of them by laying out that structure in some detail. Section 35 of the Charter of Ville de Québec provides that "the city council shall, by by-law, divide the territory of the city into wards within which a ward council may be established." Section 35.1 provides that on the application of 300 persons who are electors within the ward, or who represent a commercial, industrial, institution or community institution situated in the ward, the procedure to establish a ward council can begin. The procedure consists of a public meeting, in which a poll is held to decide on the establishment of the ward council. ${ }^{68}$ Following a majority vote of eligible voters, the city council may decide to establish a ward council. ${ }^{9}$ The city council determines, by by-law, the formalities for calling and holding ward council meetings, the responsibilities of general members and boards of directors, the term limits of the latter, as well as any other operational matters. ${ }^{70}$ All persons of full age who reside in the ward and persons of full age who represent a commercial, industrial, institutional or community institution situated within the ward are general members of the council and are entitled to vote on matters that come before the council." ${ }^{71}$ The legislation provides that councils are to be funded by the city, and that a ward council is under an obligation to report to the city council. ${ }^{72}$ The city is under an obligation to identify a set of subject matters, and establish a public consultation process with the ward council on those matters. ${ }^{73}$ In addition, the ward council may on its own initiative, give advice to the city council, the executive committee or a borough council on any matter concerning the ward. ${ }^{74}$

Each ward council is managed by a board of directors (conseil d'administration). The members of the board are elected every two years by ward members. ${ }^{75}$ Each board of

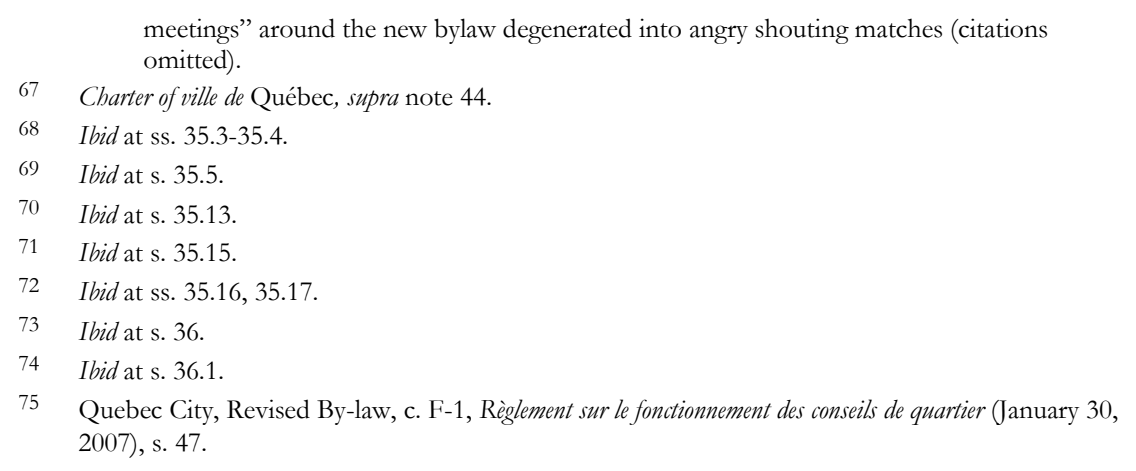


directors is comprised of four men and four women. ${ }^{76}$ In addition to these eight members of the board there is a ninth who is a representative of a commercial, industrial or institutional establishment in the ward. ${ }^{77}$ The members of the board act on a voluntary basis. ${ }^{78} \mathrm{~A}$ city councilor who represents an electoral district situated in whole or in part in the ward can be a non-voting member of the board of directors. ${ }^{79}$ It is also a practice for boroughs to put at the disposal of ward councils a facilitator (agent de consultation) who is present at all meetings of the ward councils, aids in their preparation, and ensures that the records and agendas of meetings are completed. ${ }^{80}$

In Quebec City, ward councils are mandatorily consulted on some matters. These include: the adoption or modification of an official plan for the ward council; regulations that can modify municipal services in the ward council; a development project that affects the ward; a zoning project or a major renovation of property within the ward, including a public park or recreational facilities; or a project that changes the names of streets or public places in the ward. ${ }^{81}$ More generally, ward councils are consulted by the executive committee or the borough councils concerning any project that would modify a zoning regulation and that would be the object of a public hearing or consultation. ${ }^{82}$ The practice of consultation seems to incorporate an even broader range of topics. ${ }^{83}$ Whenever the city council or its executive committee consults a ward council, the latter must inform the borough of the consultation and the ward council must submit the result of any consultation to the requesting body, as well as to the borough, which can then make recommendations. ${ }^{84}$ In addition, a ward council can initiate a consultation on any subject matter that affects the ward. ${ }^{85}$ Consultations are supported by the Service des communications et des directions d'arrondissement, which is a department within the City of Quebec charged with putting into effect the City's public consultation policy, setting out and putting into place implementation plans for the ward councils, putting into place a training program for members of the ward council and developing effective

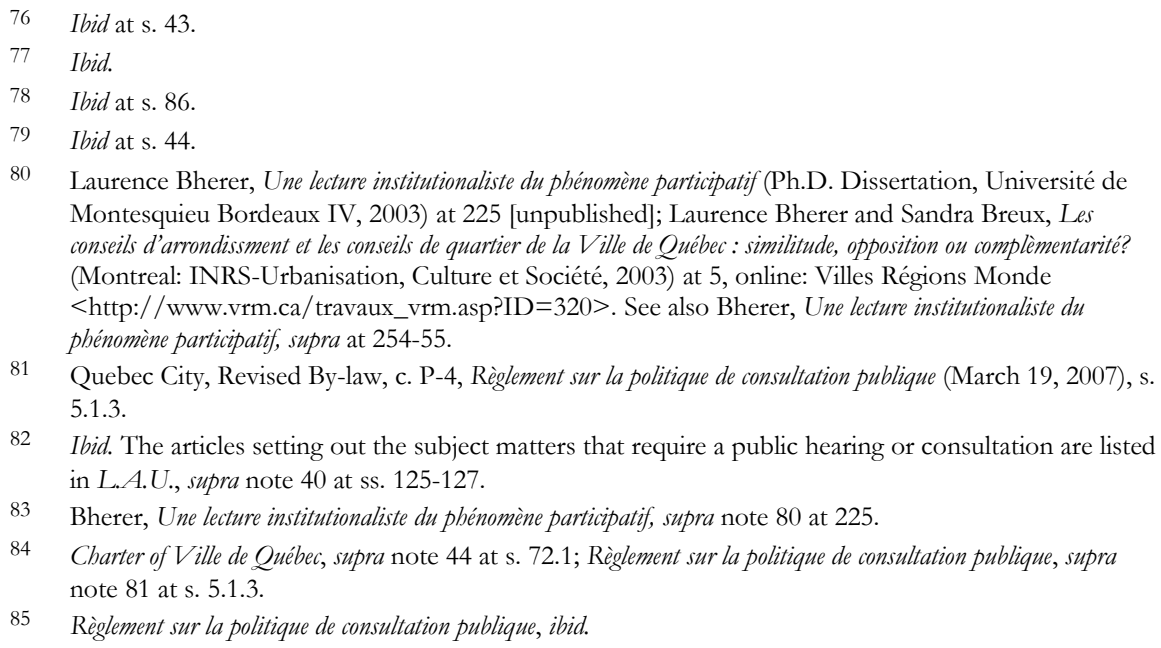

82 Ibid. The articles setting out the subject matters that require a public hearing or consultation are listed in L.A.U., supra note 40 at ss. 125-127.

83 Bherer, Une lecture institutionaliste du phénomène participatif, supra note 80 at 225.

84 Charter of Ville de Québec, supra note 44 at s. 72.1; Règlement sur la politique de consultation publique, supra note 81 at s. 5.1.3.

85 Règlement sur la politique de consultation publique, ibid. 
communication strategies. ${ }^{86}$ Ward councils are required to report to the city and the borough council on its activities in the time and manner prescribed. ${ }^{87}$

Consultations initiated by the city or a borough can take the form of a request for an opinion or of a mandate to hold a public consultation. ${ }^{88}$ Ward councils respond to requests for opinion in the course of regular meetings, which are open to the public ${ }^{89}$ By contrast, a public meeting consultation has specific publicity requirements including that the published notice provide a clear and concise statement of the project to be addressed in the consultation and of the relevant issues. A public consultation also has a specific format: the consultation begins with a statement of the issues, followed by a question period and concluding with commentary by the ward council members and an expression of their opinion of the matter. ${ }^{90}$ A report resulting from the public consultation must include a summary of the public opinions expressed in the consultation, commentary by the ward council members and recommendations." The report is sent to the body that initiated the consultation and is made available to the members of city council, the executive committee of the city and to the borough council, as well as to anyone who requests it." There is then a public announcement of the means and results of the consultation. ${ }^{93}$ Whether the ward council is consulted through the means of a request for an opinion or a public consultation, the entity that originates the consultation presents discrete options to be voted upon. ${ }^{94}$ The recommendations of the ward councils are not binding, although according to the Quebec City website they are generally followed.

\section{B. Ward Councils as Responses to the Deliberative Failures of Municipal Institutions}

Now that we have seen the structure and practice of ward councils, let us turn to consider how ward councils offer a civic republican response to the democratic deficits identified above. Consider first the problem of neglected interests. Recall that local governments are particularly susceptible to either majoritarian dominance wherein minority interests are systematically under-considered, or to special interest capture wherein the interests of the majority are disregarded. Ward councils act as a counter-weight to these tendencies by making public the views of ordinary citizens

86 Quebec City, Service des communications (last visited Apr. 28, 2010), online: Ville de Québec

$<$ http://www.ville.quebec.qc.ca/apropos/vie_democratique/administration/services_organismes_m unicipaux/dga_services_soutien/communications.aspx>.

87 Charter of Ville de Québec, supra note 44 at ss. 35.16-35.17.

88 Reglement sur la politique de consultation publique, supra note 81 at s. 5.1.4.

89 According to Professor Bherer, these requests typically involve minor matters. Bherer, Une lecture institutionaliste du phénomène participatif, supra note 80 at 226 . For an example of such a request, undertaken in the course of a regular meeting of conseils de quartier, see the minutes posted online: Ville de Québec <http://www.ville.quebec.qc.ca/docs/pv/conseils_quartier/lacite/vieuxquebec/vieux-quebec-capblanc-colline-parlementaire_0906171900.pdf>

90 Règlement sur la politique de consultation publique, supra note 81 at ss. 3.3.1-3.3.4.

91 Ibid at ss. 3.3.4-3.3.5.

92 Ibid at s. 3.3.4.

93 Ibid at s. 3.3.5. For an example of the format and result of a public consultation at a conseil de quartier, see the report online: Ville de Québec <http://www.ville.quebec.qc.ca/apropos/ vie_democratique/participation_citoyenne/conseils_quartier/vieux quebec/docs/ consultation_borne-interactive_recommandations_cq.pdf $>$.

94 Bherer, Une lecture institutionaliste du phénomène participatif, supra note 80 at 226. 
and by putting local governments in the position of either accepting or rejecting those views. Local governments must openly consider concerns that a majority or a special interest minority might prefer to ignore. This publicity function of the ward councils is consistent with that of publicity requirements in public law that compel governments to articulate their reasons for action when there is good reason to think that they are pursuing policies that evince a disregard for significant interests. ${ }^{95}$ The evidence suggests that ward councils fulfill this publicity function well: although merely advisory in nature, ward council opinions are taken seriously and they affect policy. $^{96}$

There is a serious challenge to this claim about the capacity of ward councils to address representative failings: if these failings are endemic to local governments generally, why should ward councils be exempt? One response focuses on the extent to which ward councils can act as counter-weights to majoritarian dominance within local governments. Ward councils enable groups that are minorities within boroughs or the city but that are concentrated within neighborhoods to have a voice in local government. $^{97}$ If majorities within such neighborhoods dominate proceedings and can compel elected officials to attend to a perspective that would otherwise be neglected, they act as a counter-weight to local government majoritarianism. Ward councils provide an institutionalized role for minorities, at least where minorities are concentrated in neighborhoods.

What then of the problem of special interest group capture? At the level of the borough or the city, the checking function of the ward councils is the same as in the case of majority-dominated borough assemblies or city councils. Those assemblies and councils will have to answer to otherwise under-represented groups when such groups are concentrated in neighborhoods. Moreover, if there is a majority in a city or borough that holds a view contrary to those interests that dominate the elected bodies, it will be represented in a variety of ward councils. Because consultations are mandatory in a broad range of subject matters, even if the majority of residents in a borough or city are under-motivated to participate, their voices will be heard through their boards of directors, as we shall soon see.

95 For instance, the Minister of Justice is under an obligation to report to the House of Commons any bill or regulation which, in his or her opinion, is inconsistent with the Canadian Charter of Rights and Freedoms. Department of Justice Act, R.S.C. 1985, c. J-2., s. 4.1. Similarly, under s. 33 of the Constitution Act, 1982 legislatures or Parliament can over-ride a judicial finding that legislation is unconstitutional, if they do so expressly and they renew the over-ride in five year intervals. Constitution Act, 1982, s. 33, being Schedule B to the Canada Act 1982 (U.K.), 1982, c. 11. Since five years is the maximum term of a government, this compels any government to justify its policy choice before the electorate at least once in its term. For proposals to render section 33 more deliberation-enhancing, see Tsvi Kahana, "The Notwithstanding Mechanism and Public Discussion: Lessons from the Ignored Practice of Section 33 of the Charter" (2001) 44 Canadian Public Administration 255.

96 According to the official Quebec City website (my translation): "To this point, the municipality has followed most of the recommendations of the ward councils. This attests to the importance of these institutions, which are unique to Quebec." Ville de Québec, Conseils de quartier (last visited Apr. 28, 2010), online: Ville de Québec < http://www.ville.quebec.qc.ca/ap- ropos/vie_democratique/ participation_citoyenne/conseils_quartier/index.aspx $>$.

97 For arguments in favour of local minority control of municipal institutions, see Sheryll D. Cashin, "Middle Class Black Suburbs and the State of Integration: A Post-Integrationist Vision for Metropolitan America" (2001) 86 Cornell L Rev 729. And for general arguments in favor of this kind of "inter-institutional diversity", see Heather Gerken, "Second-Order Diversity and Disaggregated Democracy” (2005) 118 Harv L Rev 1099. 
One might accept these counter-weight functions of ward councils yet still be concerned about the possibility of special interest capture or majoritarian dominance of the ward councils themselves. A response to this concern requires a consideration of the structure of ward council deliberations. Even if special interests or majorities are motivated to dominate ward council they are checked by the deliberative structure of the proceedings. The facilitator and the elected official, as well as professional staff are present to ensure that the relevant policy issues and facts are aired. If special interests or majorities attempt to dominate ward council meetings or public consultations their voices will have to contend with all others present in an environment that facilitates reasoned deliberation.

However, as authors have noted, participation rates in ward council meetings are variable and in some ward councils the level of participation is anemic. ${ }^{98}$ In such circumstances, one might worry that there are not sufficient voices to give rise to truly reasoned deliberation. .9 This concern can be met by considering the quorum rules and the structure of the boards of directors. There are three kinds of meetings: annual general assemblies, where the annual business of the ward council is conducted ${ }^{100}$ special assemblies that are convocated at the request of at least one hundred members; ${ }^{101}$ regular meetings of the board of directors, which are open to the public and public consultations. Substantive matters are not addressed in general meetings and special assemblies have quorum requirements of 50 members. There is no concern about insufficient deliberation in the first case because no meaningful deliberation occurs and there is no concern about lack of attendance in the latter case, because the quorum requirements are set sufficiently high that they answer that concern. It is in regular meetings, in which attendance is sparse, that many substantive matters arise and that the concern about numbers has most purchase.

In these, quorum is achieved when five members of the board of directors are present. The composition of the board of directors is intended to ensure broad representation. Aside from the member representing a business or organization, each member of the board is an at-large representative and there is no attempt at sectoral representation - the only attempt at demographic representation is the gender division on the board. ${ }^{102}$ The at-large nature of the representation, in combination with the deliberative procedures detailed above, aims to limit the extent to which any particular group can dominate the proceedings. The literature on group decisionmaking suggests that if representation and procedures are constructed in ways that counteract pressures which lead to over-valuing certain perspectives, groups can engage in careful and meaningful deliberation. ${ }^{103}$ The literature suggests that even in the absence of broad representation, if the relevant information is made available to them, groups can effectively deliberate about the public good if participants are

98 Bherer, Une lecture institutionaliste du phénomène participatif, supra note 80 at 257.

99 In the administrative law literature, this criticism about representativeness has been leveled against civic republicanism. See Stephen P. Croley, "Theories of Regulation: Incorporating the Administrative Process” (1998) 98 Colum L Rev 1 at 81-85.

100 Règlement sur le fonctionnement des conseils de quartier, supra note 75 at s. 5.

101 Ibid at s. 2.

102 Laurence Bherer, "La démocratie participative et la qualification citoyenne : À la frontière de la société civile et de l'État" (2006) 18 Nouvelles pratiques sociales 24 at 32.

103 See e.g. Mark Seidenfeld, "Cognitive Loafing, Social Conformity and Judicial Review of Agency RuleMaking” (2001-2002) 87 Cornell L Rev 486 at n. 92. 
willing and able to engage in such deliberation. ${ }^{104}$ And if individuals act in an institutional context that facilitates public-minded reasoning, the likelihood that they will do so increases. Given the institutional parameters within which ward councils operate, the members of the board have strong incentives to consider seriously the public interest. ${ }^{105}$

In the end, even if the problems of democratic under-representation cannot be eliminated from local governments, the structure of the ward councils aims to increase the capacity of under-represented groups to have their concerns heard within the institutions of local government and to ensure that deliberative processes incorporate diverse voices. The ward councils place municipal governments under a civic republican burden of reasoned justification for their actions. It is nonetheless possible that despite the safeguards described above, individuals or groups with intense preferences may exert disproportionate influence in ward council meetings. But if their preferences prevail, I suggest it is because of the rhetorical force of the arguments that these individuals and groups can bring to bear on the issues. We shall see that within the forum of the ward council, deliberative procedures can level the rhetorical playing field.

\section{Ward Councils as a Civic Republican Response to Defects in Municipal Deliberation}

Recall that a central problem with voluntary consultative processes is that they tend to be dominated by those who have the time to participate and who speak in the vernacular of the educated middle class and that those unable to speak in that way tend to defer to the judgments of those who can. Recall further that the consultative processes within municipalities tend to be perfunctory. The first concern about time and resources can be partially answered by noting that ward councils provide child care for those who participate in meetings and the problem of insufficient time and consideration of issues is met by the very existence of ward councils: they enable

104 Parallel institutions can cultivate and strengthen these dispositions. Edmonton provides examples of such institutions. For instance, Neighborhood Leagues are voluntary associations that support community activities and directly engage municipal governance issues. See Ron Kuban, Edmonton's Urban Villages: The Community League Movement (Edmonton: University of Alberta Press, 2005). Some modern civic republican writers stress that the state is not the only locus of value-formation and that intermediate organizations, such as Neighborhood Leagues, can serve this function. See Cass R. Sunstein, "Beyond the Republican Revival" (1988) 97 Yale LJ 1539 at 1573. In addition, municipalities can provide resources for citizens to inform themselves about substantive law, so that they may engage their officials effectively. For instance, the City of Edmonton, through its Planning Academy, provides affordable courses on the zoning process that are designed for the public. City of Edmonton, Planning Academy (last visited Apr. 28. 2010), online: City of Edmonton $<$ http://www.edmonton.ca/city_government/planning_development/planning-academy.aspx $>$.

105 Among sources of these incentives is the scale of the wards: the issues typically at stake in ward council meetings affect ward councilors' neighbours, with whom councilors have regular, face to face interactions. On the potential for such interactions to increase decision-makers' sense of accountability, see Robert Ellickson, Order Without Law (Cambridge, Mass.: Harvard University Press, 1991). On the capacity of informal norms, developed in such face-to-face encounters, to generate norms that regulate their interactions, see Robert Ellickson, The Household: Informal Order Around the Hearth (Princeton: Princeton University Press, 2008) at 102: "Relationship-specific norms are informal expectations about how each participant should behave in the future. They emerge from participants' spontaneous (i.e. unnegotiated) successes in coordinating with one another." On the general function that institutional roles play in differentiating public and private motivations, see Michelman, supra note 7. 
extended deliberation that is not possible within the standard strictures of hearing processes. ${ }^{106}$ In the remainder of this section, I will address the potential for differences in ways of speaking to influence outcomes. The deliberative resources of ward councils, which aim to counteract this source of influence, come in multiple forms. The City trains ward councilors in how to conduct meetings and as we have seen boroughs provide ward councils with facilitators. ${ }^{107}$ Moreover, professional staff and political representatives are present at meetings to provide substantive expertise. These mechanisms aim to level the discursive playing field.

Ward councils do so by setting ground-rules for discussion, structuring deliberation, training participants and distributing the relevant information to all in an accessible form. The experience of participants in similar deliberative institutions suggest that when faced with value-laden, complex and technical planning issues, ordinary citizens from diverse backgrounds can engage in informed discussions. ${ }^{108}$ In ward councils in particular, the training provided by the City, the presence of facilitators, of elected officials who have no vote and are there primarily to inform and listen, and of relevant administrators and professionals, structure the deliberative processes. Moreover, the combination of formal procedures and an informal tone in discussions creates the conditions for respectful discussion among equals. ${ }^{109}$ Formal procedures limit the ability of participants to dominate meetings, and the informal tone of discussion, coupled with the fact that participants are neighbors who have repeat dealings, reinforces the equality of participants. ${ }^{10}$

\section{Objections to the Idea of Ward Councils as Forums for Civic Republican Deliberation}

A critic might object that deliberative institutions at the local government level can at best approximate deliberative ideals and that approximations can, in certain circumstances, yield outcomes that are worse than institutions that do not take into account these ideals at all. Call this the argument from second-bests." In some circumstances, according to this argument, divisions in a polity over issues of values are so great that processes that aim at reasoned deliberation only sharpen

106 Another possibility for reducing barriers to participation is the moderated online forum. See e.g. Community Research Connections, e-Dialogues for Sustainable Development (last visited Apr. 28. 2010), online: Community Research Connections <http://crcresearch.org/research-tools/edialogues/e-dialogues>.

107 Règlement sur le fonctionnement des conseils de quartier, supra note 75 at s. 46.

108 Bherer, Une lecture institutionaliste du phénomène participatif, supra note 80 at 223. For a survey of Canadian examples, see F. Leslie Seidle, "Citizens Speaking for Themselves: New Avenues for Public Involvement" in Hans J. Michelmann, Donald C. Story, \& Jeffrey S. Steeves, eds, Political Leadership and Representation in Canada: Essays in Honour of John C. Courtney (Toronto: University of Toronto Press, 2007) 81.

109 Ibid.

110 Ibid. On the capacity of informal and formal norms to mutually reinforce practices of reasoned, nondominating deliberation, see Pettit, supra note 10, c. 8.

111 In the legal literature, the argument from second bests in the design of institutions has been treated most extensively by Adrian Vermeule, Judging Under Uncertainty: An Institutional Theory of Legal Interpretation (Cambridge, Mass.: Harvard University Press, 2006). For a discussion on this point, in the context of deliberative democratic institutions, see Jon Elster, "The Market and the Forum" in James Bohman \& William Rehg, eds, Deliberative Democracy: Essays on Reason and Politics (Cambridge, Mass.: MIT Press, 1997) 3 at 18. 
disagreement and highlight the impossibility of coming to reasoned resolutions. By contrast, the argument continues, with decision-making processes that do not stress deliberation, deep disagreements over values are not brought to open and public view, and there is no expectation that public decision-making involves anything more than responsiveness to private preferences. ${ }^{112}$ According to this objection, in a decision-making process where majority preferences determine outcomes, for example, via a simple vote, policy outcomes are achieved without open and divisive public disagreement and the social harms that deliberative processes create are avoided.

There is a second objection that can be advanced by the argument from second bests: if participants in deliberative processes do not abide by the norms of rational deliberation, the objection states, these processes may subvert deliberative ideals more than do alternatives that completely ignore them. For instance, if participants in a deliberative process seek to dominate one another they may undermine the ideals of equal respect more than they would in a simple vote through which they pursue their narrow self-interests. ${ }^{113}$ At least in the case of a vote without extensive deliberation, the argument from second bests concludes, the process itself does not subject citizens to manifest domination, although the results may.

The downside risks that the argument from second bests raises are real, but they can be mitigated by good institutional design. Consider first the problem of deep disagreements over values. One way of avoiding public and divisive expressions of differences over values is to remove issues that give rise to such divisions from the ambit of deliberative processes in public institutions. The literature on negotiated rule-making in public law suggests that issues giving rise to deeply entrenched divisions are not appropriate for resolution through negotiation, and authors therefore recommend systematically excluding such issues from negotiated-rule making processes. ${ }^{114}$ Authors who have examined the operations of ward councils suggest that issues of land use regulation typically do not give rise to deep clashes of values, and so in general, the objection is inapplicable. ${ }^{115}$ However, where such disagreements do arise, the ultimate decision-making authority lies with elected municipal representatives whose decisions are then subject to judicial review, and these institutions blunt the impact of deep disagreements among neighbours.

Consider next the objection pertaining to domination within deliberative proceedings. Here again, we can respond to the argument from second bests by

112 For a similar argument, made in the constitutional context, which stresses the potential for deliberative processes to create discord, see Jonathan R. Macey, "The Missing Element in the Republican Revival” (1987-1988) 97 Yale LJ 1673 at 1674. See also Cass R. Sunstein, "The Law of Group Polarization” (2002) 10 Journal of Political Philosophy 175.

113 This example of a failed deliberative process is not merely hypothetical. For an examination of such failures in the context of a specific deliberative initiative in Berkeley, California see Campbell \& Marshall, supra note 66.

114 See e.g. Lawrence Susskind \& Gerard McMahon, “The Theory and Practice of Negotiated RuleMaking” (1985-86) 3 Yale J on Reg 133 at 138-140, 152. On negotiated rule-making more generally in public administration, see Lawrence Susskind \& Lawrence Cruikshank, Breaking the Impasse: Consensual Approaches to Resolving Public Disputes (New York: Basic Books, 1987). Deliberative democratic theorists have attempted to identify the reasons for which issues can be excluded from discussions in the public sphere. See Amy Gutmann \& Dennis Thompson, Why Deliberative Democracy? (Princeton: Princeton University Press, 2004) at 66-78.

115 Bherer, Une lecture institutionaliste du phénomène participatif, supra note 80 at 259. 
incorporating into such proceedings good institutional design principles. The deliberative institutions surveyed above employ trained facilitators who ensure that participants have equal air-time; the processes reframe issues in language and terminology that is accessible to all; they generate rules that stress the values of discussion rather than debate; and they employ membership restrictions that aim to ensure some demographic mix. ${ }^{116}$ These and other institutional safeguards answer the objection because they create conditions in which the risk of domination is significantly lessened. Ultimately, objections leveled by the argument from second bests are empirical in nature and require on-the-ground assessments of institutions. Where institutions fail to meet deliberative ideals, and do so in ways that are selfdefeating, we should ensure that there are mechanisms that enable institutions to change and avoid these self-defeating tendencies. ${ }^{17}$

Let us consider one kind of institutional change that may respond to both objections from the argument from second bests. Instead of holding a vote to determine what the recommendation from the ward council will be on any given issue and transmitting the result to the borough or city, ward councils might only transmit an opinion to those bodies when the members of the ward council can come to a consensus. In the absence of consensus, all that would be conveyed to the borough or city would be the minutes from the ward council meeting on the relevant issue. ${ }^{118}$ Such a change in process would have several advantages. First, in those situations that give rise to deep disagreements about important values, the ward council process would not create winners or losers. Instead, elected representatives who operate at one remove from the directly deliberative institution of the ward council would engage in the weighing of interests necessary to regulate in the face of such disagreement. By removing the capacity to recommend from ward councils under conditions of deep normative disagreement, the sting of having one's neighbours make a public decision against one's deeply held convictions is lessened. Second, the proposed institutional change would provide an incentive to reach consensus, and would disincentivize hold-outs. ${ }^{19}$ In cases where there is no consensus, the ward council consultation would not affect the policy of the boroughs or the city, as those bodies would be in the position that they were in before the ward council deliberated. There would be no clear recommendation among the relevant options and

116 See Part III, A - C.

117 On self-defeating regulation, see Cass R. Sunstein, "Paradoxes of the Regulatory State" (1990) 57 U Chicago L Rev 407.

118 I thank Rod Macdonald for this example of a consensus-favoring default rule, which he observed at play in the Westmount Neighborhood Association. Consensus-favouring default rules carry risks. For instance, participants in deliberations may have a tendency to converge on a consensus because of social pressure to conform, rather than as a result of exercising their independent judgment. One way to capture the deliberative benefits of a consensus rule, while minimizing its conformity-inducing costs, is to ensure that initial heterogeneity is built into the decision-making process. If participants are initially committed to a variety of views, and the decision rule for the group stresses consensus, participants will engage in creative problem-solving activities that attempt to reconcile participants' aspirations. Steven Kelman, "Adversary and Cooperationist Institutions for Conflict Resolution in Public Policymaking" (1992) 11 Journal of Policy Analysis and Management 178 at 194-95.

119 For an influential account of hold-outs in the property context, see Michael Heller, "The Tragedy of the Anticommons: Property in Transition from Marx to Markets" (1998) 111 Harv L Rev 1621 and for an institutional proposal that aims to overcome hold-out problems, see Michael Heller \& Rick Hills, "Land Assembly Districts" (2008) 121 Harv L Rev 1465. 
participation in the ward council would be an academic exercise. Participants become involved in ward councils because they are interested in effective action and the possibility of such an inconclusive outcome would incentivize behaviours that conduce to consensus building.

\section{CONCLUSION}

In this essay, I have argued that municipal processes in Quebec, and in particular, the ward councils evidence features of a civic republican ideal of non-domination. In Part II, we saw that the processes of making zoning by-laws impose what appear to be exigent consultation requirements including, in certain cases, a requirement to hold a referendum. However, in that Part, we also saw that standard criticisms of municipal councils suggest that these consultative processes are insufficient to ensure the kind of deliberation envisioned by civic republican theory. In Part III, I argued that these standard criticisms can be answered by the ward councils and I defended, against a range of objections, the claim that ward councils instantiate civic republican ideals.

I close this essay by considering two more general objections to the approach taken by this paper. A first objection states that a standard conflict in municipal law is between local and regional interests, ${ }^{120}$ and that the deliberative procedures I have described in this paper do nothing to address this substantive conflict. A second objection states that issues of local government regulation necessarily involve the pursuit of self interest, and that the present essay's focus on theories of deliberation and on consultative bodies, misses this point.

My response to the first objection is that institutions which require the state to justify its actions have value in themselves. I do not claim to resolve the localism/regionalism debate in this paper, but I do claim that institutional mechanisms that require municipal governments to justify their governance choices to citizens are an improvement over institutional mechanisms that do not. Deliberative institutions of the kind I have described in this paper will not necessarily generate right answers to policy conundrums (indeed, such answers may not exist), but they do facilitate public deliberation and such deliberation respects the autonomy of citizens because it ensures that the state publicly justifies its actions to those who are affected by it.

I advance descriptive and normative arguments in response to the second criticism, which states that questions of local government necessarily implicate the pursuit of self-interests. The criticism is descriptively lacking insofar as it does not account for key features of municipal law. The notice and meeting requirements of municipal law and institutions such as the ward councils suggest that municipal law is concerned with public justifications for state action. ${ }^{121}$ In addition, courts impose on municipalities legislative action requirements of good faith and reasonableness, which

120 For classic treatments of the issue, in the American context, see Orfield, supra note 59; David Rusk, Cities Without Suburbs (Washington, D.C.: Woodrow Wilson Center Press, 1993); Richard Briffault, "Our Localism: Part I - The Structure of Local Government Law" (1990) 90 Colum L Rev 1; and in the Canadian context, see Marie-Claude Prémont, "La Fiscalité au Québec: de la cohabitation au refuge fiscal" (2000) 46 McGill LJ 716.

121 See in particular L.A.U. supra note 40 at ss. 130-31. 
constrain the admittedly broad discretion that municipalities enjoy in this area. ${ }^{122}$ The ward councils are simply one more institution that gives expression to this civic republican impetus of municipal law.

The normative response to accounts of municipal regulation, in which selfinterest occupies a central place, is that they misunderstand the very nature of legal regulation. Deliberative theorists have responded to the pluralist conception of the state by arguing that it is normatively indefensible. ${ }^{123}$ Authors argue that any adequate account of state action requires arguments that are sensitive to the normative particularities of state action. ${ }^{124}$ Professor Jon Elster has framed pluralist insensitivity to these particularities as evidencing confusion between the logic of the market and that of the public forum. In the market-place, the only question to be answered is: how are my preferences to be satisfied? But the public forum is driven by an entirely different set of questions. ${ }^{125}$ In the forum, we are concerned not only with our own wants, but with how decisions affect others and with questions of justice. In the forum, it is not enough to aggregate private preferences. Rather, citizens deliberate together about what the public good is and about what it requires of the state and of citizens. ${ }^{126}$ As we saw in the introduction to this paper, this normative concern animates administrative law's focus on consultation requirements in the rule-making context. This essay has argued that deliberative municipal institutions share this normative concern and I hope that the institutional design considerations and institutions that I have raised here can be transposed to other domains of the administrative state.

122 See Entreprises Sibeca Inc. V. Frelighsburg (Municipality), 2004 SCC 61, [2004] 3 S.C.R. 304.

123 For a specifically American critique along these lines, see Frank Michelman, "Law's Republic" (1988) 97 Yale LJ 1493 at 1499, 1501-03.

124 Jon Elster, "The Market and the Forum" in Bohman \& Rehg, supra note 111, 3 at 18.

125 Ibid at $10-11$.

126 Ibid at 24-25. Moreover, contrary to some theorists of democratic deliberation, Elster argues that it is not enough to deliberate for the sake of deliberation. It is in the very nature of political action that those engaged in it seek policy outcomes and do not merely pursue the intrinsic benefits of deliberation. 